\title{
FDI Spillovers and Intellectual Property Rights
}

\author{
Kiyoshi Matsubara*
}

May 2009

\begin{abstract}
This paper extends Symeonidis (2003)'s duopoly model with product differentiation to discusses how FDI spillovers that decreases the quality difference between vertically differentiated products of the home and foreign firms affects the home firm's decision on plant location. This paper shows that whether the degree of spillover is exogenous or endogenous, it may have a positive relationship with a unit trade cost including the tariff rate. It also shows that in an oligopoly model with two home firms, FDI is more likely than the duopoly case. The hypothesis in the duopoly model is supported by the cross-country regression over 41 developing/emerging economies.
\end{abstract}

JEL Classification: F12, F23, O33.

Keywords: FDI Spillovers, Intellectual Property Rights, Product Differentiation.

${ }^{*}$ College of Commerce, Nihon University. Mailing Address: 5-2-1 Kinuta, Setagaya, Tokyo 157-8570 Japan. Phone: +81-3-3749-6868. Fax: +81-3-3749-6868. E-mail: kiyoshim_00@yahoo.co.jp 


\section{Introduction}

One reason why many (developing) countries want foreign companies to enter their markets by foreign direct investment (FDI) rather than exports is that they expect technology transfers from the foreign to the domestic companies, which are more likely to occur with FDI than exports. Such technology transfer, known as FDI spillovers, has been discussed either theoretically or empirically by many economists. ${ }^{1}$ However, only a portion of spillovers, i.e. spillovers decreasing rival's production costs, and its determinants are the main focus of the study, at least in the theoretical literature.

Aitken and Harrison $(1994,1999)$ show that the entry by the foreign firm has two aspects. One is FDI spillovers, and the other is an effect of increasing competition; an decrease in output of the each domestic firm increases its average cost, even if its average cost curve is shifted downward. They argue that these opposite effects make empirical studies of FDI spillovers harder. Whether the level of spillovers is exogenous or endogenous is another issue to be addressed. Grünfeld (2006) develops a three-period duopoly model. It is assumed that a firm's marginal cost depends on R\&D investments by itself and the rival firm in case of FDI, and that FDI spillovers gets larger as its own R\&D investment gets larger. He shows that for the firm entering the foreign market, weak and strong $R \& D$ investment effects favor exports while medium-sized investment effects favor FDI.

The purpose of this paper is to explore another possible FDI spillovers that affects rival's product quality rather than its costs of producing an identical product. In the article, an duopoly model based on that of Symeonidis (2003) in which goods are vertically and horizontally differentiated. This paper consider the case when the products of the home and foreign firms are vertically differentiated and the former has higher quality than the latter. In the model, FDI spillovers are supposed to decrease the quality difference between the two products. Moreover, this article discusses the two cases; (1) exogenous spillovers: the level of spillovers is given to the both firms, and (2) endogenous spillovers: it is determined by the foreign government.

Besides extending varieties of FDI spillovers, the contributions of this work are twofold. One is to provide a framework to examine the relationship of intellectual property right (IPR) in the FDI host country with the home firm's decision on plant location, i.e. FDI vs. exports. The foreign country's IPR policy may affect the degree of FDI spillovers and thus the home firm's decision. The other contribution is to show that the level of FDI spillovers is positively related with the unit trade cost. The home firm incurs the trade costs, including tariff, when it chooses exports. This article shows a clear relationship between these two policy instruments for the foreign country.

\footnotetext{
${ }^{1}$ See Blomström and Kokko (1998) about discussions on various kinds of FDI spillovers and their channels (linkages of firms in the same or different industries, for instance). Görg, and Pisu (2008) use firm-level panel data of U.K. manufacturing industries in the 1990s with treatments of FDI-spillover channels to find substantial differences between exporting/non-exporting domestic firms in the benefits of spillovers.
} 
This paper also shows that in an oligopoly model with two home firms, FDI is more likely than the duopoly case. The hypothesis of this paper in the duopoly model is supported by the cross-country regression over 41 developing/emerging economies.

The rest of the article is arranged as follows. Section two develops the model of FDI spillovers with product differentiation, first the exogenous case and next the endogenous case. Section three extends the duopoly model to an oligopoly one with two home firms. Section four provides the empirical evidence for the prediction of the duopoly model. Section five concludes the article.

\section{Duopoly Model}

This paper develops a model based on Symeonidis (2003), who compares Cournot and Bertrand equilibria when goods are vertically and horizontally differentiated and a firm's R\&D investment changes the quality of its own product and others. Consider two countries, home and foreign, and a home firm plans to enter the foreign market either by exports or FDI. Assume that to export products to the foreign country, the home firm must pay trade costs, avoiding of which is an incentive for the home firm to perform FDI. After the decision on plant location, the home firm competes with a foreign firm by quantity with a differentiated product.

\subsection{Consumer's Utility and Product Differentiation}

Following Symeonidis (2003), consider the utility function of a representative consumer in the foreign country as follows;

$$
U=x+y-\frac{x^{2}}{u_{h}^{2}}-\frac{y^{2}}{u_{f}^{2}}-\sigma \frac{x}{u_{h}} \frac{y}{u_{f}}+M .
$$

$x$ and $y$ are quantities of the home and foreign firms' products. $u_{h}$ and $u_{f}$ are quality of the home and foreign firms' products respectively, which describe the degree of vertical differentiation. $2 \geq \sigma>0$ captures the degree of horizontal differentiation. When $\sigma$ goes to zero, the two products are totally unrelated. When $\sigma$ is equal to two with $u_{h}=u_{f}$, the two products are perfect substitutes. $M$ denotes expenditure on outside goods. Solving the consumer's maximization problem yields the following demand functions;

$$
\begin{aligned}
& p_{x}=1-\frac{2 x}{u_{h}^{2}}-\frac{\sigma}{u_{h}} \frac{y}{u_{f}}, \\
& p_{y}=1-\frac{2 y}{u_{f}^{2}}-\frac{\sigma}{u_{f}} \frac{x}{u_{h}} .
\end{aligned}
$$

In this paper, only the vertical differentiation is discussed. Thus, $\sigma=2$ is assumed in the rest of the article. 


\section{$2.2 \quad$ FDI Spillovers}

Assume that $u_{h}=1$ and that $u_{f}=(1-q) u_{h}=1-q, 0<q<1$. The second assumption implies that the home firm's product has higher quality than the foreign firm's counterpart. Suppose that if the home firm performs FDI, it results in improving the foreign firm's product by $s$. Assume that $q \geq s$. This inequality implies that the improved quality of the foreign firm's product will never exceed that of the home firm product. Assume also that production costs for both firms are zero for simplicity. Then, the profits of the two firms in each of the location mode of the home firm are as follows.

$$
\begin{aligned}
& \pi^{h}= \begin{cases}\left(1-2 x-\frac{2 y}{1-q}-t\right) x & \text { No FDI, i.e. Exports, } \\
\left.1-2 x-\frac{2 y}{1-q+s}\right) x, & \text { FDI. }\end{cases} \\
& \pi^{f}= \begin{cases}\left(1-\frac{2 y}{(1-q)^{2}}-\frac{2 x}{1-q}\right) y & \text { Exports, } \\
\left(1-\frac{2 y}{(1-q+s)^{2}}-\frac{2 x}{1-q+s}\right) y & \text { FDI. }\end{cases}
\end{aligned}
$$

$\pi^{h}$ and $\pi^{f}$ are profits of the home and foreign firms respectively. $t>0$ is a unit trade cost.

From the first order conditions, quantity produced by the each firm in the each case is the following. When the home firm chooses exports (Case $E$ ),

$$
\begin{aligned}
& x_{E}=\frac{1+q-2 t}{6}, \\
& y_{E}=\frac{(1-q)(1-2 q+t)}{6} .
\end{aligned}
$$

For the outputs to be positive, $2 q-1<t<\frac{1+q}{2}$ are assumed. When the home firm chooses FDI (Case $F$ ),

$$
\begin{aligned}
& x_{F}=\frac{1+q-s}{6}, \\
& y_{F}=\frac{(1-q+s)(1-2 q+2 s)}{6} .
\end{aligned}
$$

For the outputs to be positive, $q-\frac{1}{2}<s$ are assumed. In either cases, the quality differences $q$ or $q-s$ have positive effects on the output of the home firm while they always have negative effects on the output of the foreign firm. To explore the effects of FDI spillovers $s$, a case when $s$ is given to the both firms is discussed first. Then a case when $s$ is endogenously determined is considered.

\subsubsection{Exogenous Spillovers}

Suppose that the level of FDI spillovers is $s_{0}$ and that it is given to both the home and foreign firms. By inserting the equilibrium outputs in each case to the profits (1) and (2), it is shown that $\pi_{h}=2\left(\frac{x_{i}}{u_{h}}\right)^{2}$ and $\pi_{f}=2\left(\frac{y_{i}}{u_{f}}\right)^{2}$, where $i=E, F$. This implies that to see which production location gives higher profits to the home firm, 
comparing the outputs of the home firm in the two cases is enough to compare the profits in the two cases. From equations (3) and (5), the equilibrium outputs of the home firm in the two cases, in order for the home firm to prefer FDI, the following inequality must hold;

$$
s_{0}<2 t \text {. }
$$

The following result summarizes the above discussion.

Result 1 If the degree of FDI spillovers is less than $2 t$ where $t$ is the unit trade cost, the home firm chooses FDI. Otherwise, the home firm chooses exports.

\subsubsection{Endogenous Spillovers}

Suppose that before the home firm decides its plant location, the foreign government may determine the degree of FDI spillovers $s$ and the unit trade cost $t$ through its IPR and trade policies. For simplicity, $t$ is assumed to be equal to the tariff rate.

The welfare of the foreign country is defined as the sum of the consumer surplus and the profits of the foreign firm (and the tariff revenue in case of exports). The consumer surplus is derived by substituting $M=I-p_{x} x-p_{y} y$ into the utility function where $I$ is the consumer's income assumed to be given and thus can be ignored in the analysis. When the home firm chooses exports (case $E$ ), the consumer surplus is

$$
C S_{E}=\left(x_{E}\right)^{2}+\frac{2 x_{E} \cdot y_{E}}{1-q}+\frac{\left(y_{E}\right)^{2}}{(1-q)^{2}} .
$$

When the home firm chooses FDI (case $F$ ), the consumer surplus is

$$
C S_{F}=\left(x_{F}\right)^{2}+\frac{2 x_{F} \cdot y_{F}}{1-q+s}+\frac{\left(y_{F}\right)^{2}}{(1-q+s)^{2}} .
$$

Next, the welfare in case $E$ is

$$
\begin{aligned}
W_{E} & =C S_{E}+\pi_{f}^{E}+\text { Tariff Revenue } \\
& =\left(x_{E}\right)^{2}+\frac{2 x_{E} \cdot y_{E}}{1-q}+\frac{3\left(y_{E}\right)^{2}}{(1-q)^{2}}+t \cdot x_{E} \\
& =\frac{1}{6}+\frac{q(3 q-4)}{12}+\frac{t(2-3 t)}{12} .
\end{aligned}
$$

On the other hand, the welfare in case $F$ is

$$
\begin{aligned}
W_{F} & =C S_{F}+\pi_{f}^{F} \\
& =\left(x_{F}\right)^{2}+\frac{2 x_{F} \cdot y_{F}}{1-q+s}+\frac{3\left(y_{F}\right)^{2}}{(1-q+s)^{2}} \\
& =\frac{1}{6}+\frac{q(3 q-4)}{12}+\frac{s\{2(2-3 q)+3 s\}}{12} .
\end{aligned}
$$


The first two terms are common for the both welfare measures, so it is enough to compare the third terms to determine which location is better for the foreign country.

Suppose that $s=2 t$. If this equality holds, the home firm is indifferent between exports and FDI (inequality 7 ). Substituting $2 t$ into $s$ of $W_{F}$, the difference in welfare between FDI and exports is

$$
W_{F}(s=2 t)-W_{E}=2(1-2 q) t+5 t^{2} .
$$

If $\frac{1}{2} \geq q$, the difference is nonzero. Even if $q>\frac{1}{2}$, the difference is nonzero because $2 q-1<t<\frac{1+q}{2}$ (positive output condition in case of exports). Therefore, when $s=2 t$, the foreign welfare with FDI is never less than that with exports.

Suppose that from $s=2 t, s$ increases while $t$ is not changed, which increases $W_{F}$ while $W_{E}$ is unchanged. However, $s$ is now greater than $2 t$, so the home firm chooses exports. Therefore, any pair of $(s, t)$ where $s>2 t$ is not chosen by the foreign government. What if $s$ is not changed while $t$ increases? This change makes $W_{F}$ unchanged. Whether $W_{E}$ increases or decreases depends on the level of $t$. $W_{E}$ is maximized when $t=\frac{1}{3}$. Even when $t$ is set at $\frac{1}{3}$, if $s>\frac{3(3 q-2)+\sqrt{9(3 q-2)^{2}+9}}{9}$ or if $s>\frac{3(3 q-2)-\sqrt{9(3 q-2)^{2}+9}}{9}$, the third term of $W_{F}$ is greater than $\frac{1}{3}$, the maximum of the third term of $W_{E}{ }^{2}$ Because the foreign government wants to set $s$ at the possible highest level, $W_{F}>W_{E}$ holds.

The following result summarizes the above argument.

Result 2 Suppose that the foreign government may choose the levels of the FDI spillovers and the tariff rate before the home firm decides its plant location. Then, the foreign government prefers FDI and chooses $s$ and $t$ satisfying the following conditions for a given q, quality difference between the home and foreign firm products.

1. $s=q<2 t$.

2. $2 q-1<t<\frac{1+q}{2}$.

Result 2 shows that in the model, the tariff rate is set at a high level to induce the home firm to FDI for a given quality difference. It implies that countries with firms producing low quality goods might set high tariff rates and at the same time implement loose IPP. Figure 1 shows the area $(s, t)$ that the foreign government may choose to maximize the foreign welfare. Figure 1 suggests that for given quality difference, the tariff rate may be positively correlated with the degree of FDI spillovers. The degree of FDI spillovers may be negatively correlated with IPP in the foreign country, so Results 2 imply that the tariff rate may be negatively correlated with IPP.

\footnotetext{
${ }^{2}$ Whether the first or second inequality is applied depends on the level of $q$. If $q<\frac{2}{3}$, the first inequality is applied and otherwise.
} 


\section{Extension: Oligopoly Model}

In this section, we examine whether a change in the number of the home firm from one to two makes any difference on the FDI condition for the home firm. Assume that the two home firms are identical, i.e. the quality of the products of the two home firms are the same. Assume also that FDI spillovers are exogenous for the all firms, and that if one home firm chooses FDI, the spillover occur. Three cases should be examined; (1) both of the two home firms, $h_{1}$ and $h_{2}$, chooses exports, (2) both of the two home firms chooses FDI, and (3) $h_{1}$ chooses exports while $h_{2}$ chooses FDI. Case (3) is new with this oligopoly model, which could make some difference from the duopoly model.

In cases (1) and (2), the two home firms produce the same quantity. In case (1), quantity produced by the home and foreign firms are as follows:

$$
\begin{aligned}
x_{1}=x_{2}=x_{\text {case } 1} & =\frac{1+q-2 t}{8}, \\
y_{\text {case } 1} & =\frac{(1-q)(1-3 q+2 t)}{8} .
\end{aligned}
$$

In case (2), quantity produced by the home and foreign firms are as follows:

$$
\begin{aligned}
x_{1}=x_{2}=x_{\text {case } 2} & =\frac{1+q-s}{8}, \\
y_{\text {case } 2} & =\frac{(1-q+s)(1-3 q+3 s)}{8} .
\end{aligned}
$$

In case (3), the two home firms choose different locations. The profits of the three firms are the following.

$$
\begin{aligned}
\pi^{h_{1}} & =\left\{1-2\left(x_{1}+x_{2}\right)-\frac{2 y}{1-q+s}-t\right\} x_{1}, \\
\pi^{h_{2}} & =\left\{1-2\left(x_{1}+x_{2}\right)-\frac{2 y}{1-q+s}\right\} x_{2}, \\
\pi^{f} & =\left\{1-\frac{2 y}{(1-q+s)^{2}}-\frac{2\left(x_{1}+x_{2}\right)}{1-q+s}\right\} y .
\end{aligned}
$$

$h_{1}$ must pay trade costs due to its choice of exports. Note that spillover occurs because $h_{2}$ chooses FDI. Outputs of the three firms are:

$$
\begin{aligned}
x_{1}^{\text {case } 3} & =\frac{1+q-s-3 t}{8}, \\
x_{2}^{\text {case } 2} & =\frac{1+q-s+t}{8}, \\
y_{\text {case } 3} & =\frac{(1-q+s)(1-3 q+3 s+t)}{8} .
\end{aligned}
$$

Table 1 is the payoff matrix of the two home firms. In each cell, the first number is the quantity produced by $h_{1}$, and the second one is that produced by 
$h_{2}$ respectively. ${ }^{3}$ When one firm chooses FDI, the other firm also chooses FDI. However, when one firm chooses exports, the other firm's choice depends on which number, $-2 t$ or $-s+t$, is larger. $-2 t$ is the cost of choosing exports. $-s+t$ is the sum of the cost and the possible benefit of choosing FDI . The following result is the FDI condition with two home firms.

Result 3 Suppose that the two home firms enter the foreign market by FDI or exports. If $s<3 t$, the both firms chooses FDI. Otherwise, multiple equilibria occur: (1) the both firms chooses exports, and (2) the both firms chooses FDI. However, when $s>3 t$, the export equilibrium gives higher profits to the both home firms than the FDI equilibrium.

The FDI condition with one home firm is $s<2 t$. Therefore, Result 3 shows that an increase in the number of the home firm makes FDI, i.e. spillovers, more likely. This is a kind of prisoner's dilemma: unless the degree of spillovers is very high $(s>3 t)$, the both home firms have an incentive to deviate from the (exports, exports) equilibrium. The deviating home firm could decrease the competitiveness of the other home firm substantially by the effects of spillovers and trade costs. When the FDI condition holds, however, the both home firms deviate. Thus, an asymmetric equilibrium does not occur.

In the next section, about the relationship between IPP and tariff rate discussed in Section 2, some cross-country evidence is provided.

\section{IPR policy and Trade Cost: Cross-Country Evidence}

Figure 2 provides some evidence for Result 2 in Section 2, by examining crosscountry variations of the strength of IPP and of the level of tariff rate. In the Figure, the horizontal axis is simple-average tariff rate of non-agriculture products of each of 41 developing/emerging countries, from WTO international trade and tariff data.

The samples consist of 16 Central and South American and Caribbean countries (Argentina, Bolivia, Brazil, Chile, Colombia, Costa Rica, Ecuador, El Salvador, Guatemala, Honduras, Jamaica, Mexico, Nicaragua, Paraguay, Peru, Uruguay), 15 African countries (Botswana, Cameroon, Egypt, Ghana, Kenya, Malawi, Mauritius, Morocco, Namibia, Nigeria, South Africa, Senegal, Tunisia, Zambia, Zimbabwe), and 10 Asian and Middle Eastern countries (China, India, Indonesia, Jordan, Malaysia, Pakistan, Philippines, Republic of Korea, Thailand, Vietnam). Some of the sample countries are developing by trade/investment liberalization, so they are in the similar situation with the foreign country in the model of this article.

The vertical axis of the Figure is Intellectual Property Score calculated by Lesser (2002), who shows that IPP measured by the index has positive significant effects

\footnotetext{
${ }^{3}$ In Table 1 , the denominators, 8 , are omitted.
} 
on inward FDI and imports. In the Figure, a higher IP Score means stricter IPP. Consistent with the prediction by Result 2 of this paper, the IP score is negatively related with the tariff rate.

\section{Conclusions}

This paper extends Symeonidis (2003)'s duopoly model with product differentiation to discusses how FDI spillovers that decreases the quality difference between vertically differentiated products of the home and foreign firms affects the home firm's decision on plant location. This paper shows that whether the degree of spillover is exogenous or endogenous, it may have a positive relationship with a unit trade cost including the tariff rate. As an extension, this paper discusses the case of two home firms and shows that FDI is more likely than the duopoly case. The hypothesis from the duopoly model is supported by the cross-country regression over 41 developing/emerging economies.

This study may be extended in several ways. First, to examine the effect of market structure, more oligopoly models with many homogeneous or a small number of heterogeneous home or foreign firms can be possible options. Especially, effects of joint venture between the foreign and the home firms may be an interesting issue to be addressed. Second, to discuss the home country's or world welfare and a policy game among countries, introducing the home government and/or home market is another research agenda. Third, developing the empirical analysis in Figure 2 is another direction of research. For instance, tariff is not the only factor of the unit trade cost, so the robustness of the result should be examined more.

\section{References}

[1] Aitken, Brian J., and Ann E. Harrison, "Do Domestic Firms Benefit from Foreign Direct Investment?" World Bank Policy Research Working Paper No. 1248 (February 1994).

[2] , "Do Domestic Firms Benefit from Foreign Direct Investment? Evidence from Venezuela." American Economic Review, Vol. 89, No. 3 (June 1999): 605-618.

[3] Blomström, Magnus and Ari Kokko, "Multinational Corporations and Spillovers." Journal of Economic Surveys, Vol. 12, No. 2 (1998): 1-31.

[4] Girma, Sourafel, Holger Görg, and Mauro Pisu, "Exporting, Linkages and Productivity Spillovers from Foreign Direct Investment." Canadian Journal of Economics, Vol. 41, No.1 (February 2008): 320-340.

[5] Grünfeld, Leo A., "Multinational Production, Absorptive Capacity and Endogenous R\&D Spillovers." Review of International Economics 14(5) (November 2006) 922-940. 
[6] Lesser, William, "The Effects of Intellectual Property Rights on Foreign Direct Investment and Imports into Developing Countries in the Post TRIPs Era." IP Strategy Today, No.5 (2002).

[7] Symeonidis, George. "Comparing Cournot and Bertrand equilibria in a differentiated duopoly with product R\&D" International Journal of Industrial Organization 21 (2003) 39-55. 


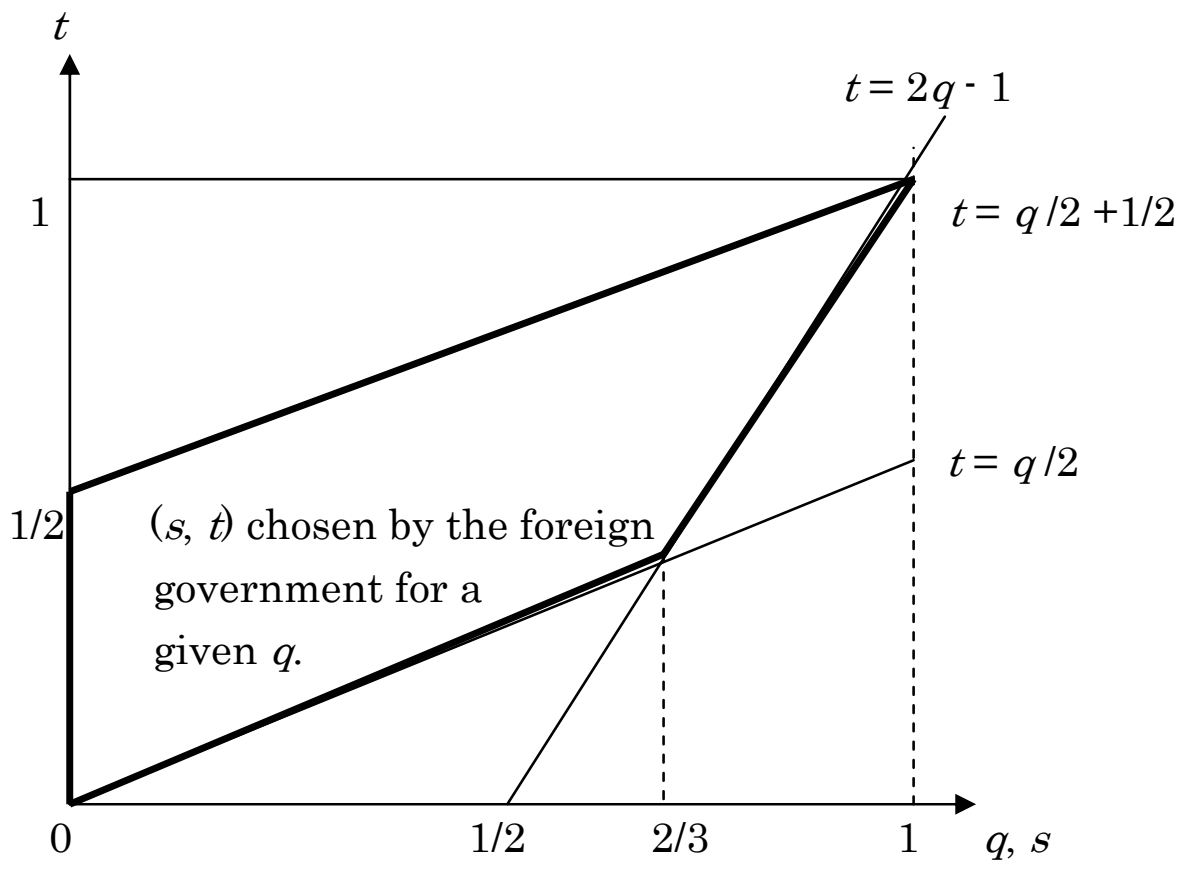

Figure 1 Illustration of Result 2.

\begin{tabular}{|c|c|c|}
\hline $\mathrm{h}_{1} / \mathrm{h}_{2}$ & Exports & FDI \\
\hline Exports & $1+\mathrm{q}-2 \mathrm{t}, 1+\mathrm{q}-2 \mathrm{t}$ & $1+\mathrm{q}-\mathrm{s}-3 \mathrm{t}, 1+\mathrm{q}-\mathrm{s}+\mathrm{t}$ \\
\hline FDI & $1+\mathrm{q}-\mathrm{s}+\mathrm{t}, 1+\mathrm{q}-\mathrm{s}-3 \mathrm{t}$ & $1+\mathrm{q}-\mathrm{s}, 1+\mathrm{q}-\mathrm{s}$ \\
\hline
\end{tabular}

Table 1 Payoff matrix of the two home firms. 
Figure 2 Average Non-Agriculture Tariff and Strength of Intellectual Property Protection: Cross-Country Analysis

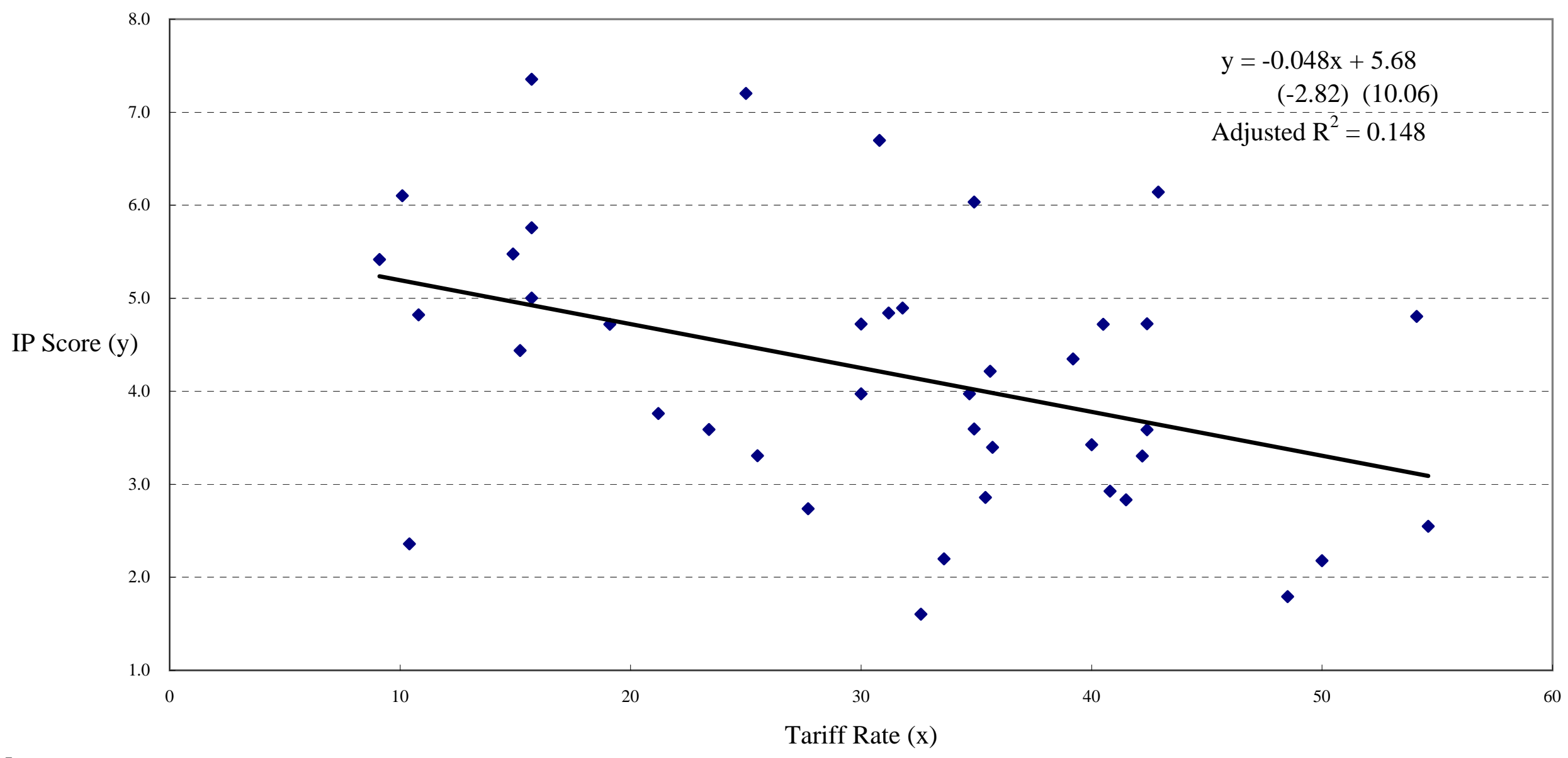

Notes

1. Tariff rate $=$ Simple average based on pre-aggregated HS six-digit averages. Source: WTO international trade and tariff data.

2. IP score is from Lesser (2002).

3. $\mathrm{t}$-values are in parentheses. 